\title{
Archival Studies in Ukraine: Between Tradition and Challenges of Information Era
}

\author{
MARYNA PALIIENKO, PH.D. \\ Department of Archival Studies and Special Historical Disciplines, Taras Shevchenko National University of \\ Kyiv, Ukraine \\ e-mail: mpaliienko@gmail.com
}

\begin{abstract}
Archival Studies in Ukraine: Between Tradition and Challenges of Information Era
\end{abstract}
\section{ABSTRACT}

The article it devoted to analysis of the new trends in the archival education in Ukraine connecting with evolution of society and archives in information era. The author explores the models of archival education in Ukraine in a context of a new archival paradigm. Special attention is given to the activity of the Archival Studies Department at Taras Shevchenko National University of Kyiv which offers a distinctive training program on archival theory, history and methodology as well as on Source Studies and Auxiliary Sciences of History. However, the challenges of a new information era led to the establishment in some centers for records managers' training. Nowadays educators and archivists recognize the necessity of modernizing archival training programs, bringing them to the contemporary needs and archival practice. The author offers her view on getting balance between History, Memory, and Informational Technologies at the Archival Studies' curricula.

Key words: archives, archival training, Ukraine, history, information technologies

Studi archivistici in Ucraina: fra tradizione e sfide dell' era informatica

\section{ABSTRACT}

L'articolo è dedicato all' analisi delle nuove tendenze nella formazione archivistica in Ucraina in connessione con l'evoluzione della società e degli archivi nell'era informatica. L'autore esplora i modelli di formazione archivistica in Ucraina nel contesto di un nuovo paradigma d'archivio. Particolare attenzione è data all'attività del Dipartimento di studi archivistici Taras Shevchenko dell'Università nazionale di Kiev, che offre un programma di formazione particolare in teoria archivistica, storia e metodologia, nonché studi delle fonti ausiliarie della storia. Tuttavia, le sfide di una nuova era informatica ha condotto all'istituzione in alcuni centri per la formazione dei responsabili dei documenti. Al giorno d'oggi i docenti e gli archivisti riconoscono la necessità di modernizzare i programmi di formazione adeguandoli alle esigenze contemporanee ed alla pratica archivistica. L'autore offre la sua visione su come ottenere equilibrio tra storia, memoria e tecnologie informatiche nel curriculum degli studi archivistici.

Parole chiave: archivi, formazione archivistica, Ucraina, storia, tecnologie informatiche

$$
\text { Študij arhivistike v Ukrajini: med tradicijo in izzivi informacijske dobe }
$$

\section{IZVLE $\check{C} E K$}

Članek je posvečal analizi novih trendov v arhivskem izobraževanju v Ukrajini, ki povezujejo z razvojem družbe in arhivov v informacijski dobi. Avtor raziskuje modele arhivskega izobraževanja v Ukrajini v kontekstu nove arhivske paradigme. Posebna pozornost je namenjena dejavnost Oddelka za arhivoslovje na Narodni univerzi Taras Shevchenko v Kijevu, ki ponuja poseben program usposabljanja o arhivski teoriji, zgodovini in metodologiji ter o izvornih študijah in pomožnih znanostih o zgodovini. Vendar so izzivi nove informacijske dobe pripeljali do ustanovitve v nekaterih centrih za vodenje evidenc menedžerjev. Danes izobraževalci in arhivisti priznavajo potrebo po modernizaciji programov arhivskega usposabljanja, ki jih usklajujejo s sodobnimi potrebami in arhivsko prakso. Avtor ponuja svoj pogled na pridobivanje ravnotežja med zgodovino, spominom in informacijskimi tehnologijami v kurikulumih arhivskih študijev.

Ključne besede: arhiv, arhivsko izobraževanje, Ukrajina, zgodovina, informacijske tehnologije 
Maryna PALIIENKO: Archival Studies in Ukraine: Between Tradition and Challenges of Information Era, 181-188

Архівні дослідження в Україні: між традицією і проблемами інформаційного століття

\section{АНОТАЦІЯ}

Стаття присвячена аналізу новітніх тенденцій у розвитку архівної освіти в Україні, які розглядаються у контексті еволюції суспільства та архівів в інформаційну епоху. Автор досліджує сучасні моделі архівної освіти в Україні крізь призму нової архівної парадигми. Спеціальна увага приділяється діяльності кафедри архівознавства у Київському націонацьному університеті імені Тараса Шевченка, яка здійснює викладання курсів з архівної теорії, історії та методології, а також джерелознавства та спеціальних історичних дисциплін. Відзначається, що потреби інформаційного суспільства призвели до заснування низки освітніх центрів із підготовки управлінців документацією. Сьогодні архівісти та викладачі визнають необхідність модернізаціі університетських програм навчання, наближення їх до потреб сучасного інформаційного середовища та архівної практики. Автор пропонує свій погляд на досягнення балансу між історією, пам'яттю та інформаційними технологіями при скмаданні програм навчання.

КАючові слова: архіви, архівна освіта, Україна, історія, інформаційні технології

\section{Introduction}

Evolution of the archival profession deals with the crucial changes in political, socio-cultural and informational environment. It actualizes the necessity of rethinking the conception of archival training.

Since the first half of the $19^{\text {th }}$ century and until recently in the archival field the European model of archival education has been dominated and it was based on a deep study of the historical disciplines at universities, such as paleography, diplomatics, sigillography, as well as on an extensive language training. Therefore, it led to the formation of the professional community of the historians-archivists, editors and publishers of historical monuments who were deeply acquainted with medieval sources and could interpret their texts professionally.

These educational standards have been implemented in a number of European archival schools during the $19^{\text {th }}$ century (in particular, at L'École des Chartres in Paris, the Bavarian Archival School in Munich, the School of Archivistics, Paleography and Diplomatics of the State Archives of Rome, the Vatican School of Paleography, Diplomatics and Archives Administration). Historical disciplines are still playing a key role in educational programs for Austrian archivists (from 1854 and till nowadays the archivists are training at the Institute of Austrian History Research at the University of Vienna).

These traditions were reflected in the publications of Luciana Duranti (1988), Paule René-Bazin (1992), Roy Schaeffer (1994), Angelika Menne-Haritz (2000) and others. In one of my earlier researches I made a comparative analysis of the historical evolution of the European and American models of archival education (see Палієнко, 2015). However, few writers have been able to draw on any systematic research into the evolution of archival training in Ukraine, especially in comparison with world tendencies. Among Ukrainian authors, who studied the problems of genesis and development of archival education, it is worth noting Jaroslav Kalakura (see Karakypa, 2008 \& 2014), Iryna Matiash (see Mamsu, 2000), Natalia Makovska (sеe Маковська, 2002). But up to now, the Ukrainian researchers have tended to focus more on the national background; meanwhile in this article I will be trying to examine this issue at interdisciplinary level and in the international context.

\section{Archival Training from the Ukrainian Perspective}

Referring to the Ukrainian experience at this field it is worth noting that archival education traditionally was based on the historical background. First attempts of organized archival training in our country took place in Kyiv, Kharkiv and Odessa in the 1920s (at the short-termed professional courses for archivists, as well as at the archival departments of Archeological institutes). From the mid-1930s archival training process became fully centralized and transferred to Moscow where the State Institute for History and Archives was founded that now operates in the structure of Russian State Humanitarian University.

But in 1944, during the final years of World War II, the Department of Archival Studies was cre- 
ated at the Kyiv State University. For years it has become the main educational center for archivists in Ukraine. An important contribution to the development of the Ukrainian archival education was made by the well-known historians, such as D. Bahalij, M. Dovnar-Zapolskyi, V. Veretennikov, V. Romanovskyi, O. Vodolazhchenko, V. Strelskyi, V. Zamlynskyi, Ja. Kalakura.

Over the years more than 800 historian-archivists graduated from the Department of Archival Studies of Taras Schechenko University. A large number of our graduates became the professional archivists and now many of them continue working at the central and regional state archives, as well as at the archival and manuscript departments of the National Library, museums and in some business archives. In addition, the Department as a scientific center prepared 20 Doctors of Science and more than 60 Candidates of Science (History) (see Kaлакура \& Щербак, 2014, p. 344).

Archival Studies at Taras Shevchenko University closely connected with Source Studies and Auxiliary Sciences of History. The teaching of these subjects has a long tradition at our university. Several generations of Archival Department's professors developed valuable courses on Archival and Source Studies, Paleography, Diplomatics, Chronology, Genealogy, Heraldry, History of Public Institutions, Archeography (publication of historical documents) etc. During the last two decades our Archival Department in cooperation with the Ukrainian Research Institute of Archival Affairs and Records Keeping and other academic institutions prepared an educational and methodical complex of archival textbooks for university students, among them: "Archival Science" (Kyiv, 1998; $2^{\text {nd }}$ ed. - 2002), "Historical Source Studies" (Kyiv, 2002), "Essays on the History of Archival Affair in Ukraine" (Kyiv, 2002), "Special (Auxiliary) Historical Disciplines" (Kyiv, 2008) etc. We are also working on the development and standardization of archival terminology, taking part in such projects as "Archivistique: terminology" (1998) and "Ukrainian Archival Encyclopedia" (2008).

It should be underlined that the cooperation of Archival Department with state archives and academic institutions has been deepened during the last two decades. We coordinate our activity with the State Archival Service of Ukraine, the Ukrainian Research Institute of Archival Affairs and Records Keeping, state archives, M. S. Hryshevsky Ukrainian Institute of Archeography and Source Studies of the National Academy of Sciences of Ukraine.

Meanwhile, the last decades of the $20^{\text {th }}$ century actualized the necessity for training specialists in the field of records management that was caused by a significant increase in documentary as well as the rapid development of new information technologies and implementation of electronic documents. Since the mid-1990s - the early-2000s records management has been taught at Bachelor's and Master's programs at several Ukrainian universities, such as the National University of Ostroh Academy (Department of Document Studies and Information Activities), the National Academy of Government Managerial Staff of Culture and Arts (Department of Informational Communication and Librarianship), Kharkiv State Academy of Culture (Department of Records Management), National Aviation University (Department of History and Records Management, Humanitarian Faculty), etc.

Crucial debates, devoted to the actual problems of the archival education's further development, are ongoing at the international archival meetings as well as on the pages of professional journals. Some scholars and educators express an opinion that it will be better to continue training on the university historical background, while others believe that it would be better to give a more pragmatic sense and join with the training of librarians and information managers in common schools. As Paule René-Bazin stressed at the beginning of the 1990s, "archivist requires both general and specialized training", "the future of European archival education has to be considered within this context of historical, national, and international identities and institutions" (René-Bazin, 1992, p. 58).

In Ukraine a new conception for archival training began to develop in the end of the 1990s with the participation of the Ukrainian Research Institute of Archival Affairs and Records Keeping (head of authors Iryna Matiash) and Taras Shevchenko National University of Kyiv (prof. Jaroslav Kalakura). At that time it included multi-level structure of the training of archivists, in which the first level devoted to the pre-professional training of the undergraduates (bachelor's level), the second level - basic education for professional archivists at the historical departments of the universities; the third level - basic training for specialists in information technologies and documentation at the librarian and information departments of the universities; the forth level - retraining and certification training of leading specialists of archival institutions at the Archival Center for Postgraduate Studies (see Mamsıu ma iH., 1998). It was 
also included an opportunity of postgraduate and doctoral studies for preparation of the highest level specialists.

It should be noted that in the 1990s doctoral thesis in the field of Archival Science were prepared at some universities and academic institutions and defended by specialty Historiography, Source Studies and Special (Auxiliary) Historical Disciplines (code 07.00.06). Since 2002 a new specialty for obtaining scientific degrees in the field of Archival Science, Documentary Science (code 07.00.10) has been launched. Conception of this specialty was developed by the Ukrainian Research Institute of Archival Affairs and Records Keeping (head of the authors prof. S. Kuleshov). This innovation had a significant impact on the training of archivists in Ukraine. In 2008, despite the principal position of the Research Institute as well as the Archival Department of Taras Shevchenko National University this specialty was transferred from the field of History to the field of Social Communication (specialty code: 27.00.02). This decision caused some contradiction between the supporters of training archivists at the historical faculties of the universities, on the one hand, and librarian and documentation departments of the institutes of culture, on the other hand. However, according to the new passport of specialties it became possible to prepare archival thesis in the field of History as well as Social Communication. Eventually it had a positive impact on widening the research topics and deepening ties between different disciplines and spheres.

During the existence of Specialized Academic Council in the Ukrainian Research Institute of Archival Affairs and Records Keeping (2003-2015) there were defended 55 thesis for the degree of Candidate of Science, including 32 papers - on specialty Historiography, Source Studies and Special (Auxiliary) Historical Disciplines, and 23 - on specialty Archival Science, Documentary Science (Горбатюк, 2015). It should be emphasized that a number of leading archivists from central and regional Ukrainian archives received their scientific degrees and improved their professional skills during this period, among them Yu. Kovtaniuk (director of the Central State Electronic Archives), T. Klymenko (director of the State Archives of Cherkasy Region), V. Kupchenko (director of the State Archives of Kyiv Region), I. Maha (director of the Central State Archives of Foreign Ucrainica). In addition, there are postgraduate studies in specialty Archival and Documentary Science at the V. I. Vernadskyi National Library of Ukraine.

But it should be stressed that the vast majority of graduates from the records management specializations do not continue their professional activity at archival institutions. They prefer to work in records keeping sphere dealing with modern documents and management processes. It causes problems in the archival field that are connected with aging staff. According to the statistical data, on January 1, 2016 there were 4074 employees at the all Ukrainian state archives. Analysis of the archivists' age structure proves that their largest group consists of people aged from 46 to 55 years old (30\% of all archival staff). Meanwhile the proportion of young people under 35 years is only $26 \%$ (sее Аержавна архівна служба України, 2015).

Of the total numbers of employees $72 \%$ have a higher (including university-based) education. This is a very high figure. But among them only $2 \%$ have diplomas of historian-archivists; $11 \%$ of specialists have diplomas in History, meanwhile 59\% have complete higher education in other fields, and 5\% of specialists have Master's degree in the State Management's branch of knowledge. The scientific degrees have 80 archivists (sеe Аержавна архівна служба України, 2015).

\section{Archival Education: How to Get Balance between History, Memory, and Informational Technologies?}

The next part of this paper will consider the relations between different components at the modern archival curricula in Ukraine. As explained earlier, over the past few decades, it has been launched a process of gradual withdrawal of Archival Science from their historical roots. Ultimately it led to exclusion of Archival Science from the sphere of History (according to the latest list of specialties that was adopted by the decree of the Cabinet of Ministers of Ukraine in April 29, 2015, № 266). As a result, it was created a new specialty "Information, Library and Archival Affairs" (branch of knowledge 02 - Culture and Arts, code of specialty 029). All these innovations actualize prospects of further training of archivists in Ukraine in a whole, and particularly at the Historical Faculty of Taras Schevchenko National University of Kyiv, where, as it was mentioned above, more than 70 years ago the first Archival Department in Ukraine was established. 
We recognize the necessity of modernizing our educational programs, bringing them to the needs of contemporary world and archival practice which are constantly broadening and evaluating. As Terry Eastwood pointed out in his article in Archivaria, archival curricula has to get "a conjunction between what the students need to know and what practitioners have to do" (Eastwood, 1996, p. 80). Nowadays, choosing further vector of the development of archival education in Ukraine, we have to bring it closer to the requirements of time and to the international educational standards.

It is also essential to take into account that Archival Science through its multifunctional character has administrative, law, historical, socio-cultural and informational components. Consequently, it is important to implement different specializations at Master's level. To my mind, one of them should continue training of archivists-historians, with deep knowledge in the field of Source Studies and Auxiliary Historical Disciplines; while the others should provide training of archivists and records managers well-acquainted with informational technologies. We emphasize that training of the archivists should include the historical research as its important component. Master's and Doctoral programs must be based on a combination of lectures, internship and intense research activity.

We should remember that university education during the $19^{\text {th }}$ and $20^{\text {th }}$ centuries has created a proper background for the development of Archival Science, and also brought recognition to its representatives in the scientific community. It is not possible to reduce archives' and archivists' functions only to society's informational needs.

During the last decades debates are being held about the relationship between history and archives. In this connection I would like to underline that archives preserve the historical memory of mankind and, consequently, they are determined as the institutions of social memory. That is why not only records managers and information technologists must play an important role in their activity, but also archivists-historians who will continue traditions of the European archival schools that were linked with history and auxiliary disciplines. Meanwhile, a significant percentage of subjects should be appropriated to modern requirements including courses of records management, information technologies, management of electronic records, access to information and freedom of its use. Modern archival education needs deeper integration of archival theory and practice, mobility of students and teachers, their participation in the international educational and archival projects.

But at the same time we should remember that drafting university curricula for Archival Studies cannot be only internal university process. Professional archivists should be actively involved in their formation. I am fully agreed with Elizabeth Shepherd who emphasized that "we need to establish the respective roles of academics and professionals (and of universities and of archives) and provide mechanisms and funding for both to share ideas and skills and to work collaboratively" (Shepherd, 2006).

Archival curriculum in Ukraine must take into consideration valuable experience of cooperation between university departments and professional archival associations accumulated by our foreign colleagues. The Ukrainian universities have to adopt their curriculum to the new professional environment. Nowadays it is important to teach future archivists to use computer technologies for solving theoretical and practical tasks as well as prepare them for administrative activity during their university studies. As it was noted by Spyridoula Arathymou in her article, published in Atlanti, "an archivist needs to have deep knowledge on various scientific fields, apart from his archival education and training. An archivist has to know history, paleography, chemistry, various languages and management and recently he owes to be fuent in the new technologies" (Arathymou, 2012, p. 102).

New challenges require the archivists to develop new skills. It is very important now to enlarge number of courses devoted to the full continuum of the documents' life cycle. It is necessary to provide course on using computer technique in archival practice. Modern archivists should keep in touch with electronic records. At our department we deliver courses on Records Keeping and Records Management. Two years ago I also started a course at Magisterial level devoted to Digital Archives and Archival Information Resources. It should be noted that we have a lot of problems in this sphere, especially technical ones. But we are trying to have some practical classes at archives in cooperation with the Central State Electronic Archives of Ukraine and other archival institutions. Last year we organized with participation of the Documentary Department of National Aviation University, Central State Electronic Archives of Ukraine, Lithuanian State Modern Archives, and Kaunas County Archives the Ukrainian-Lithuanian Scientific Archival Seminar "Digital Space and Archives" (March 2016). 
At the same time we need to remember about the key role of archives and archivists in social and cultural life of society, their mission as the keepers of collective memory. From that point of view, it is extremely important to extend connections of Archival Studies with historical and cultural disciplines. History as a branch of knowledge cannot exist and develop without archives and primary sources as well as archives cannot be properly organized and functioned out of their historical background. The roots of Archival Science deeply tied with History, and nowadays despite the fact that Archival Science is an independent branch of knowledge with wide interdisciplinary connections, it is still important to teach upcoming archivists historical disciplines. We should remember that the Committee on Professional Training and Education of the International Council on Archives in 1994 adopted recommendation which stated that a balance between history and other sciences should be established in Archival Studies.

Important problems of archival training were discussed during some international meetings, in particular at the $7^{\text {th }}$ European conference on archives that was entitled "Archivist-Profession of the Future in Europe" (Warsaw, 2006). Meanwhile connections between archives, history and memory were focused at the $15^{\text {th }}$ International Congress on Archives "Archives, Memory and Knowledge" (Vienna, 23-27 August 2004).

The essential role in understanding the archives' and archivists' mission in contemporary world played the Report on Archives in the enlarged European Union (2005) that was elaborated by the National Experts Group on Archives of the EU-Member States and EU-Institutions and Organs at the request of the Council of the European Union. As indicated in this document, European citizens mainly associate archives with Memory and History. Consequently, the archivists is considering as the guardians of the social memory who transmit authentic evidence of human activity and experience through time. In this comprehensive survey of modern archives' development, European experts outlined that mission of archivists involves promoting democracy, accountability and good governance.

The archivists as memory's keepers and builders have to understand the cultural and historical values of documents; they also have to be aware of the political, economical and socio-cultural processes of different historical epochs because they are responsible for evaluation and selection of the documents for permanent storage. Archivists link generations; they transfer knowledge about the past to the present and save it for the future.

That is why at Kyiv University we are trying to save and develop traditions of Archival Training in the framework of Faculty of History. Our students during their Bachelor's studies learn basic history subjects, methodology, and auxiliary historical disciplines. From their second year they also specialize in Archival Science and have professional-oriented courses, such as "History of Archival Affairs", "National Archival Fond", "History of State Institutions", "Archeography" (Documents' Publishing). Our Magister's Programme include courses in "Archival Theory and Methodology", "Archival Legislation", "Foreign Archives and Comparative Archival Studies", "Foreign Archival Ucrainica”.

\section{Conclusion}

Nowadays we extremely need innovations in curricula for modern archival training. As Eric Ketelaar stressed out, "a new "archivistics" demands that archival education be comparative and multi-disciplinary" (Ketelaar, 2000, p. 322). Our essential task is to participate in developing national competency standards for archival training together with the Association of Ukrainian Archivists. We are conscious that it is not possible to prepare a universal specialist in the framework of one university programme but we pursue the goal to shape multifaceted personality that is able to meet contemporary professional challenges. The education has to create an intellectual framework that enables graduates to continue mastering their skills during their professional career.

We have to combine different learning strategies and introduce more courses on the socio-cultural role of archives, develop interdisciplinary links and communication skills. In this context we are trying to involve our students in the process of preparing documentary exhibitions, to promote archives and their importance to a wide-range of users through Internet resources and by posts on social networks. Our students help us to create and maintain the web-site of Archival Department (see http://archives.knu.ua) as well as its page on Facebook.

The educational programs need to include special courses for particular types of archives (religious, 
business, ethnical, etc.). One of the important challenges of our time is to prepare new generation of archivists to the activity in business sphere, especially in economic and business archives, that needs new competences and skills.

We also have to take into account that international experience enriches national and local practice. Nowadays there are much more opportunities for archival institutions, professional associations and educators in Ukraine to develop partnerships with foreign colleagues, to share with them ideas and knowledge. As Eric Ketelaar noted, comparative archivistics is dealing with global "archives without boundaries" (Ketelaar, 2000, p. 330).

Ukrainian archivists have to "pass the Rubicon" of the $21^{\text {st }}$ century archival paradigm and together with universities create a basis for integration the national traditions of Archival Science, education and practice into the European socio-cultural environment. We must move out of our traditional boundaries, create and widespread the new positive image of an archivist.

\section{References}

Arathymou, S. (2012). Long Life Training for Archivists: A Present and a Future Challenge. In: Atlanti, 22 (2), pp. 101-104.

Duranti, L. (1988). Education and the Role of the Archivist in Italy. The American Archivist, 51 (Summer), pp. 346-355.

Eastwood, T. (1996). Reforming the Archival Curriculum to Meet Contemporary Needs. In:Archivaria. 42 (Fall), pp. 80-88.

Ketelaar, E. (2000). Archivistics Research Saving the Profession. In: The American Archivist, 63 (Fall/Winter), pp. 322-240.

Menne-Haritz, A. (2000). Archival Training in a Changing World. The American Archivist, 63 (Fall-Winter), pp. 341-352.

René-Bazin, P. (1992). The Future of European Archival Education. In: The American Archivist, 55 (Winter), pp. 58-65.

Report on Archives in the enlarged European Union (2005). Increased archival cooperation in Europe: action plan. Elaborated by the National Experts Group on Archives of the EU-Member States and EU-Institutions and Organs at the request of the Council of the European Union. Available at: ec.europa.eu/transparency/regdoc/ $\mathrm{rep} / 1 / 2005 / \mathrm{EN} / 1-2005-52-\mathrm{EN}-\mathrm{F} 1-2 . \operatorname{Pdf}$ (accessed on 17.03.2017).

Schaeffer, R. (1994). From Craft to Profession: The Evolution of Archival Education and Theory in North America. Archivaria, 37 (Spring), pp. 21-34.

Shepherd, E. (2006). Is Archives and Record Management a Profession for Practitioners or an Academic Discipline? In: VII European Conference on Archives (Warzawa, May 18-20, 2006). Archivist: Profession of the Future in Europe. Available at: 20090209.archiwa.gov.pl/.../E_Shepherd_Is\%2 (accessed on 07.03.2017).

Горбатюк, М. (2015). Сучасний стан підготовки наукових каАрів вищої кваліфікації дмя архівної галузі У країни. In: Матеріали Всеукр. (зміжнарод. участю) наук.-практ. конф. «Архіви -наука -суспільство: иляхи взаємодї̈» (Київ, 21-22 mpавня 2015 p.). Available at: http://undiasd.archives.gov.ua/doc/konferenciji/21-22_05_2015/mater-conf-21-22_05_2015.pdf (accessed on 27.02.2017).

Аержавна архівна служба України: підсумки діяльності у 2015 рочі та пріоритети на 2016 рік (2015). Київ. Available at: www.archives.gov.ua/Archives/Zvit_2015.pdf (accessed on 17.03.2017).

Калакура, Я. (2008). Архівознавчий осередок Шевченкового університету. Архіви України, 1-2, pp. 158-169.

Калакура, Я., Щербак, М. (2014). 70 років архівознавчій кафедрі Київського університету. Архіви України, 4-5, pр. 338-345.

Маковська, Н. (2002). Професійна архівна освіта в Україні: моделі, іміАж, перспективи. Архіви України, 1-3, pp. 46-54.

Матяш, І., Калакура, Я., Аозицький, В., Селіверстова, К. (1998). Концепція підготовки та післядипломної освіти каАрів амя архівних установ. Студї з архівної справи та документознавства, 3, pp. 17-25.

Матяш, І. (2000). Архівна наука і освіта в Україні 1920-1930-хроків. Київ. 592 с.

Палієнко, М. (2015). Історичні традиції та сучасні тенденції розвитку європейської та американської модемей архівної освіти. Архіви України, 5-6, рр. 35-60. 


\section{SUMMARY}

Evolution of the archival profession deals with the crucial changes in political, socio-cultural and informational environment. It actualizes the necessity of rethinking the conception of archival training. The educational standards, that have been implemented in a number of European archival schools during the $19^{\text {th }}-20^{\text {th }}$ centuries, was based a deep study of the historical disciplines at universities, such as paleography, diplomatics, sigillography, as well as on an extensive language training. The development of Archival Studies in Ukraine was closely connected with Source Studies and Auxiliary Sciences of History. For more than seventy years the archivists-historians have been graduated from the Taras Shevchenko National University of Kyiv, where the Department of Archival Studies was founded in 1944. Since the end of the 1990s the training programs for records managers, librarians and information specialists have been launched in some Ukrainian universities. Then a new specialty for obtaining scientific degrees in the field of Archival and Documentary Sciences was founded in 2002. New challenges of Information Era require the archivists to develop new skills. Nowadays it is very important to enlarge number of courses devoted to the full continuum of the documents' life cycle. Archival Science through its multifunctional character has administrative, law, historical, socio-cultural and informational components. Consequently, it is essential to implement different specializations at Master's level. On the one hand, modern archivists should keep in touch with electronic records; on the other hand, archivists as memory's keepers have to link generations and transfer knowledge about the past to the present, and save it for the future. Today is extremely important to maintain balance between theory and practice in training programs. Professional archivists should be actively involved in the formation of university curricula for Archival Studies. Ukrainian archives, archivists, professional associations and educators have to develop partnerships with their European colleagues, participate in innovative projects on historical heritage preservation and usage, promoting democracy, accountability and good governance.

Typology: 1.04 Professional Article

Submitting date: 18.02 .2017

Acceptance date: 05.05.2017 